\title{
Interiority and the Conditions of Interior
}

Mark Pimlott

Delft University of Technology

The Netherlands

\begin{abstract}
Interiority pertains to the individual's inner life, rich and set in opposition to the pressures of the world. This interiority has been allied with notions of the exclusive space or refuge of the interior. As a realm of privacy and subjectivity, of projections and receptions, the interior has come to be considered as a realm that, although profoundly affected by infiltrations of the world without, is 'responsive' to the individual at its centre. As such, it is a realm of illusions. However, there is another order of interior, a condition of interior, wherein spaces, settlements and territories are ideological realms of constructed narratives and imagery within which the individual subject is given illusory impressions of freedom. Interiority's turn toward the imagination suggests that freedoms can be found despite these determinations. Public interiors have the obligation to realise this, and exemplars have offered places for gathering and interaction, promoted freedoms of movement, association and action, and advocated consciousness of the self and others.
\end{abstract}

Keywords: interiority, condition of interior, public interior, allusion, radical subjectivity, instrumentality 
In the English language, the word 'interiority' denotes 'inner character' ${ }^{\prime 2}$, and infers a condition of inwardness and individual contemplation. It pertains to the individual, who in withdrawing from the world to enter a world of one's own, achieves a kind of freedom. I wish to address this kind of freedom in relation to another order of interior, one of urban, territorial and even global scale that is subject to the effects of ideology and its agreements: a condition of interior, in which interiority may offer an emancipatory respite. The retrieval of the experience or perception of 'freedom' within this interior, which touches upon the room and the space of the city alike is an urgent matter, particularly in response or resistance to the prevalent ideology of neoliberalism. A sense of the means through which this might be attempted is a matter of urgency for designers and architects of the interior.

In April 2016, Richard Sennett gave a lecture on the matter of Interiors and Interiority at Harvard University Graduate School of Design. He began by describing the standard account of the development of the interior-and the notion of the interior-as we are familiar with it. According to this account, before modernity, affairs pertaining to the interior were not considered especially distinct from those of the world outside, and that a notion of privacy germane to the interior was not really developed until the middle of the eighteenth century, when differentiated rooms appeared whose natures were distinct from public space. The interior as an increasingly specialised realm at once offered a retreat from the world for the self, and a place in which subjectivity could flourish. The company of one's intimates would allow the individual to feel free to express oneself. This was reflected in one's dress, which differed between the public and private realms: clothing specific to one's place in society or work would be worn in public, and one would be able to comport oneself in another way to familiars in the protected and private realm of the interior. These conditions produced an atmosphere-in Sennett's words-of "openness, frankness and sharing" that constituted interiority.

The nineteenth-century European novel produced evidence that the interior could also be said to be a realm of the imagination and revelation; a realm of allusion, illusion, and in some notable

Oxford English Dictionary: Interiority: *inner character: "the profound interiority of faith"

${ }^{2}$ The main character, Des Esseintes, is a dandy: bored, self-indulgent, and cruel. The house he makes for himself, and constantly refurbishes, reflects his ever-shifting preoccupations and tastes. Interiors are decorated strange colours, surfaces, patterns and effects; very rare books supply intellectual weight; plants that evoke states of mind and body (such as exotic flowers that stink like death); and metaphors for his own indolence and decadence abound, including a tortoise whose shell has encrusted with jewels, moving across the floor slowly (and so burdened, soon dies). 
instances, such as Joris-Karl Huysmann's fictional creation, the character Des Esseintes ${ }^{2}$ in his novel $\grave{A}$ Rebours (1884), a realm of fantasy and excess. The book's protagonist was at a remove from the world, and so created his own world, with its own codes: the interior represented a constantly unfolding attempt at (self-) realisation that produced a condition of interior that was both extreme and exclusive.

In his lecture, Sennett (1903) described interiority through the thoughts of Georg Simmel's essay 'The Metropolis and Mental Life'. Simmel had proposed that it was the street rather than the home or the community that produced subjectivity within the individual. Simmel presented the metropolitan citizen as an agonist who appears in the street and responds to its space of excessive stimulation with externally blasé behaviour, all the while being affected by that space. The street and exposure to others thus produced feelings and thoughts: subjectivity, individuality, and interiority. Simmel described the metropolitan subject as capable of observing complex external conditions and harbouring quite distinct thoughts simultaneously, and this without the interference of others or the engagement demanded by the domestic interior and its familiars. In the street, one could be detached from others, and develop a reflective position; and, through being able to observe external conditions without interaction or direct involvement, one could experience a kind of freedom.

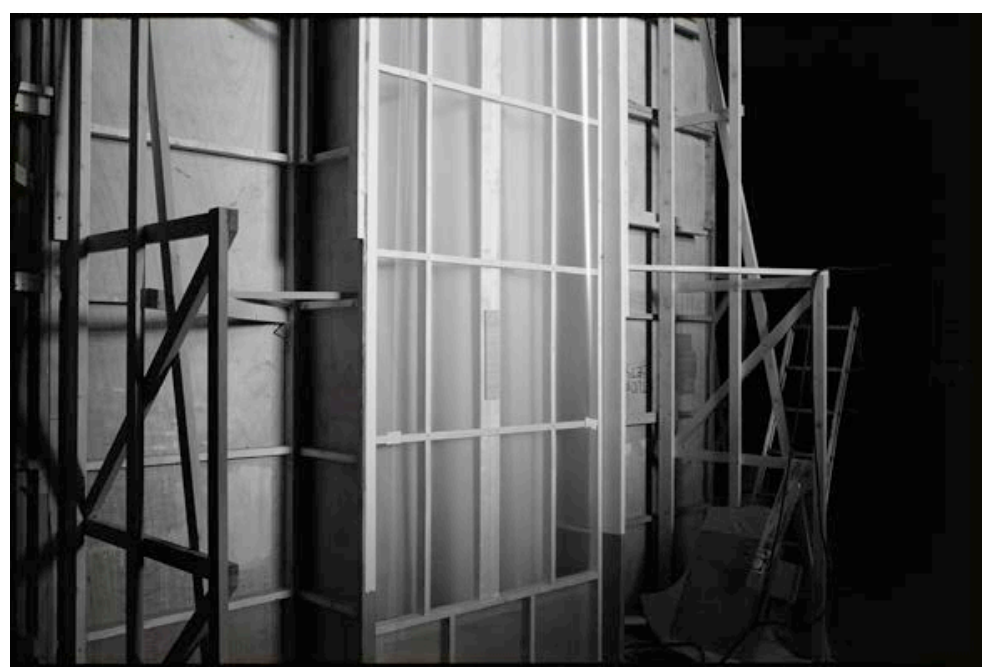

Figure 1

Paris F 1994

(fenêtre)

(c) Mark Pimlott

In contrast, the interior bound to the family or the small familiar community-what is described as the domestic interior-typically does not sustain this kind of freedom; indeed, it has characteristically suppressed it. The commonplace experience of young people moving from village or suburb to the city, in which freedom of 
movement, association and action translates to personal freedom, illustrates this. ${ }^{3}$ Familial and spatial intimacy, and other structures and strictures of the domestic interior construct a condition of interior through prescribed codes of behaviour to which an individual is subject. In the street, however, one is able to act and feel and move about as one's true self while within oneself, among many others, and experience, simultaneously, inwardness and freedom. This interiority and its freedom act as defences to the condition of interior produced by the domestic setting and the metropolitan setting alike. Sennett's lecture is important for us because it helps us to establish terms. Here, interiority is-whether associated with the familiar, domestic interior or the unyielding metropolis-located in the individual: it is a condition, however, produced by the environment. Here, I wish to broaden the definition what the interior can be, and outline a condition of interior that is extensive, pervasive, and insists on repetitive tropes and agreement. I have written about this before in relation to interiorisation at the scale of the North American continent-the continental interiorand described the means and devices colonisation as producing a condition of interiority (Pimlott, 2007). In retrospect, I regard the term I used-interiority-as inaccurate: rather, the processes and means of colonisation produced a condition of interior. These processes may be seen to be continuous, in that the devices through which laissez-faire capitalism operated, and which were represented in the dispersed urban environment, were extensions of those processes of colonisation that preceded them; and that a similar extension may be seen in the projective operations, devices and expressions of global capitalism or neoliberalism, which similarly produce a condition of interior, or what Peter Sloterdijk (2013) has called 'The World Interior of Capital'.

\section{Interiority and Subjectivity}

Interiority, as experienced by the individual, seems to suggest one means of resisting the condition of interior. The kinds of freedom produced by interiority reside in the possibilities for reflection that are produced by the environment. The creation of reflective distance as a reaction to the exaggerated stimuli of the metropolis is central to the work of writers and photographers who have observed, recast and reinterpreted the city in forms that are significant to them, following their deliberate but subjective attentions. In his

\footnotetext{
${ }^{3}$ In his lecture, Richard Sennett speaks about his own research in Muslim cities, and Cairo in particular; and of his conversations with women regarding wearing the burqa in public. He was told by many women that when they wear their burqa in the street, they feel free in their anonymity, temporarily liberated from the structures and strictures of the home placed upon them by their relatives, children and husbands.
} 
'Arcades Project' (1927-1940), Walter Benjamin interpreted the interbellum metropolis of Paris through an inquiry into its creation in nineteenth-century modernity, through the scenes, artefacts and fictions of its neglected arcades, or passages (Benjamin, 1999). Guy Debord (1957) reconfigured the same city on the basis of montages of fragments of experience, or unités d'ambiance, in his 'Guide psychogéographique de Paris'. Recently, Ian Sinclair has described London through the device of walking, reconfiguring the city through subjective readings of its scenes and streets in books such as Lights Out for the Territory (2003), and The Last London (2017). The writer and filmmaker Patrick Keiller, who, through his protagonist 'Robinson', also contemplated "the problem of London" (1994), calls this mode of re-configuration "radical subjectivity" (2014), a process through which the city assumes features that are meaningful for those individuals who interpret them. In these interpretations, the city does not appear as something other than itself, but as a bearer of myriad embedded narratives and histories that are significant, and which the individual makes their own.

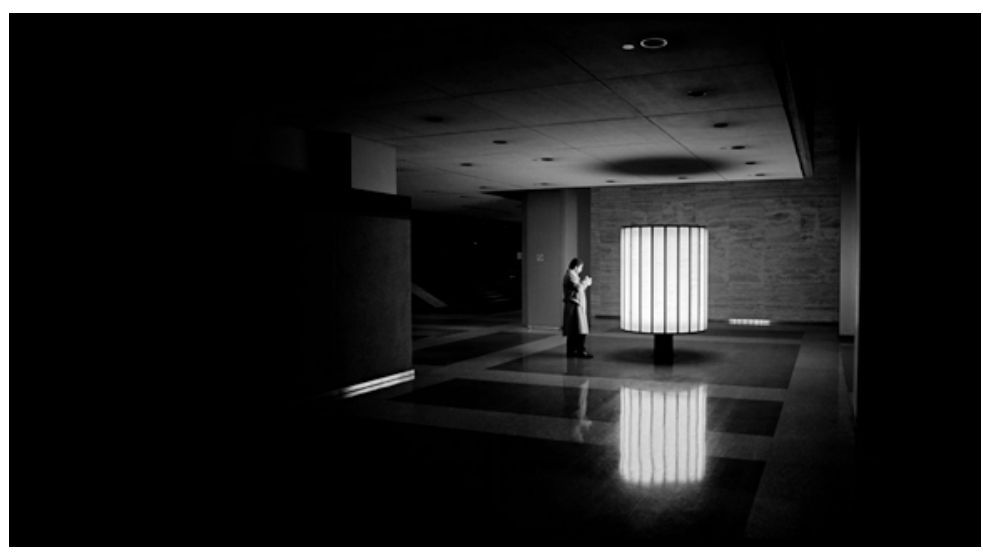

Figure 2

Montréal CA 1991

(c) Mark Pimlott

Psycho-geography is also the domain of topographic photographers who attend to the world as it manifests itself or appears at a particular, representative moment which, through the making of an image, re-presents that moment of perception of the world (Shore, 2006, 2007). The renowned American photographer Stephen Shore discovered that: "the camera was the technical means of showing what the world looks like at a moment of heightened awareness. It is that awareness, of really looking at the everyday world with clear and focused attention, that I'm interested in" (Shore, 2002, 2004, 2008). In Shore's work, the photograph becomes the register of a moment or condition through which the world reveals itself, and which produces instances of profound interiority in the photographer and viewer. In contemplation of these subjective interpretations, 
itineraries, and images, the city-presently metropolitan, global and neoliberal, despite all local specificity-is shown to be a locus for highly charged readings and associations which it prompts through its myriad and interdependent manifestations: topographies, architectures, interiors, and others. It is clear that possibilities for individual reflection and interiority abound within the apparently rigid agendas set by the city and its environments; and that the interiority the city produces within its citizens suggests possibilities for resistance to its shaping of individual and mass experience. Here, the term 'city' pertains to the dispersed and diffuse total urbanised environment, formed by power relations and their residue, the effects of capital, and currently shaped by the effects of neoliberalism. Interiority, as specific to the experience of the individual, is difficult to accommodate as a programme for those who must think about the making of the city and its interior; however, we must attend to its possibility because of the freedoms it enables. To do so, we, as designers and architects of the interior, must make placesand particularly public interiors-of specific character, materiality, atmosphere and evidence of relations, through which people may be more conscious of themselves and others, the world and their place in it.

Before returning to examples of how such places have been made in the past or might be achieved in the future, it is important to show instances of the development of the condition of interior on a territorial scale, as a basis for understanding the contemporary ubiquity or omnipresence of this condition, and the dimension of our task, our obligation; and to help identify possibilities for the production of environments of genuine richness and freedom.

\section{The Condition of Interior}

The production of a condition of interior would seem to have been one of the necessary objectives of colonising empires throughout history, to aid the control of territories of others and the subjugation or elimination indigenous populations, and the expropriation of their resources. The creation of a condition of interior is evident in the case of Roman military outpost settlements, such as Timgad, now in Algeria (100CE), which set apart a place in the world, cut boundaries in the earth to render the settlement distinct from the world, and, using a grid, laid out space within those boundaries to create a representative order-of politics, worship and behaviourfor life therein (Rykwert, 1976): the Roman settlement was an interior cut out of the space of the world, and a condition of interior prevailed within its walls, which would then be deployed without. 
The procedures, rituals and measures that attended the Roman settlement could be implemented anywhere. The establishment of such settlements in far-flung places was important for the process of colonisation undertaken by the Roman Empire throughout the Mediterranean, Asia Minor, and northern Europe. As outposts, the settlements placed a claim upon the territory around, enforced by military presence, and administrative means thereafter. Their square form, defined walls with entry points at the ends of the cardinal routes of planning, the cardo and decumanus, and the distribution of forum, monuments, temples, theatres, baths and ordinary buildings therein, all constituted the representation of Roman civic and administrative order and Roman ideology. There were two layers to the condition of interior created by the Romans: one pertaining to the settlement itself, and another to the territory beyond the settlements' walls, which was subject to systematised legislation, agriculture, and connective networks (Branzi, 2006).

The settlement as the basic element of the Roman colonial system was an idealised construction that represented Roman organisation and method, rather than a reflection of how Rome was actually organised or made (Gargola, 2017). As the Roman settlement was at first a military camp, so too were the colonial outposts of European colonial enterprises, established from the sixteenth through the nineteenth centuries, around the Mediterranean, in continental Africa, the Americas, the West Indies, Asia Minor, Southeast Asia, the East Indies the Far East and Oceania. You will be familiar with the form of these from Batavia to Savannah: the British, Dutch, Spanish, Portuguese, French, and latterly the Germans, Italians and Japanese all had imperial ambitions which had trade and militarism-with genocide or slavery-working in consort. Bases would be established that were fortified against both indigenous populations and competitors. Within these, a condition was created that combined pragmatism and idealism and projected notions of order emanating from those Empires' hearts, or from their agents, such as, in the case of the Netherlands and Batavia and Indonesia, the East India Company. With varying measures and means, the lands under new 'masters' submitted to new orders, new systems, and a narrow range of purpose, concerned with the extraction of resources, the enforcement or inducement of local populations to service that extraction, and the maintenance of order to sustain that service. Long-term involvements were tied to the wealth of resources in the colony, including the labour of the local population. For all of this to work, the colonial ruling cadre needed to maintain control and a condition of interior had to be sustained, one that for pragmatic reasons, frequently mixed representational and organisational tropes of both the local population and the colonial occupiers. 


\section{The American Condition of Interior}

A particularly powerful instance of this is embodied in the projective acts that supported the colonisation of the United States and the American West. These acts combined the interests of capital, industry, government and military power; created new origin myths that sustained these interests; and yielded new spatial conditions that emerged in the environment as it was planned and built (Pimlott, 2007). The American example provided a pattern for planning and architecture that transpired to be perfectly suited to laissez-faire capitalism, and to easy dissemination to other distant environments primed for its reception. This 'American space', and in particular, its way of treating the public interior, has been and continues to be pervasive, worldwide. It is familiar in forms such as the shopping mall (Sorkin, 1992) and the continuous interior, what Rem Koolhaas has characterised as "Junkspace" (Koolhaas, 2000). The American model, originating in the strategies for interiorising the American West, has been used to generate total environments for the organisation of society around commercial imperatives, driven by small groups of business interest and their investors. The American space proceeded on the basis of projective strategies from the time of the establishment of British colonies: it, along with everything within it, was intended to be possessed, from the east coast (upon which the British, French and Spanish had arrived) to the west, as far as it would go, the continental territory, as yet unknown, divided like slices of cake (Maumi, 2007).

It was initiated by Thomas Jefferson's Land Ordinance (1785), a projective system that served multiple purposes. A grid, both abstract and operative, was designed for the survey of land and its division thereafter, determining property boundaries from the scale of territories to those of townships and individual properties, the layout and relations within those townships, and the measures and dimensions of materials to build them. This was a serious development in the history of colonisation: specificity was removed from its method of process (Benevolo, 1978), and so, too, the notion of resistance. An abstract system was conceptualised and enshrined in legislation, which then operated in the manner of a machine. This system was deployed indifferently over topographies and others who were unseen and unknown. Difficult terrains were subsumed by the grid; others were disregarded. The idea of a tabula rasa was thus established, which required the elimination of indigenous populations, both to command natural resources and to lay claim on a purified territory for American (white, European) settlers. The displacement of the other was achieved through military force and various claims on their domains: those of industry who claimed 
natural resources, and those of settlers who were encouraged to claim and inhabit land and render it productive. The Homestead Act of 1865 offered land cleared of indigenous populations to those who would make it useful, thus tying the 'American space' to notions of possession through labour, and 'defence' against the other. Therein lies the present-day attachment to gun ownership, its concomitant antagonism toward the other and claims on individual property and liberty: the other being any of either the defeated, the enslaved, the foreigner, or the government. The physical characteristics of the continental territory were transfigured into a repertory of mythical imagery, and so the grid-at once abstract and physical-gathered representations into its network. At one level, this was consistent with the displacement, replacement and assumption of the indigenous other and the place of the other; on another, it was essential to the creation of representational 'figures' through which the condition of interior could be identified and continually renewed. In the second half of the nineteenth century, the American space was cast as a God-given 'garden' for white, European settlement-central to the attendant ideology of Manifest Destiny-whose latent imagery authenticated its occupation and notions of individual realisation through labour that achieved that occupation. Thereafter, the logic of the grid was coupled with the mechanics of laissez-faire development, and the repertory of mythical imagery was-and continues to be-deployed to legitimate the ongoing project of urbanisation.

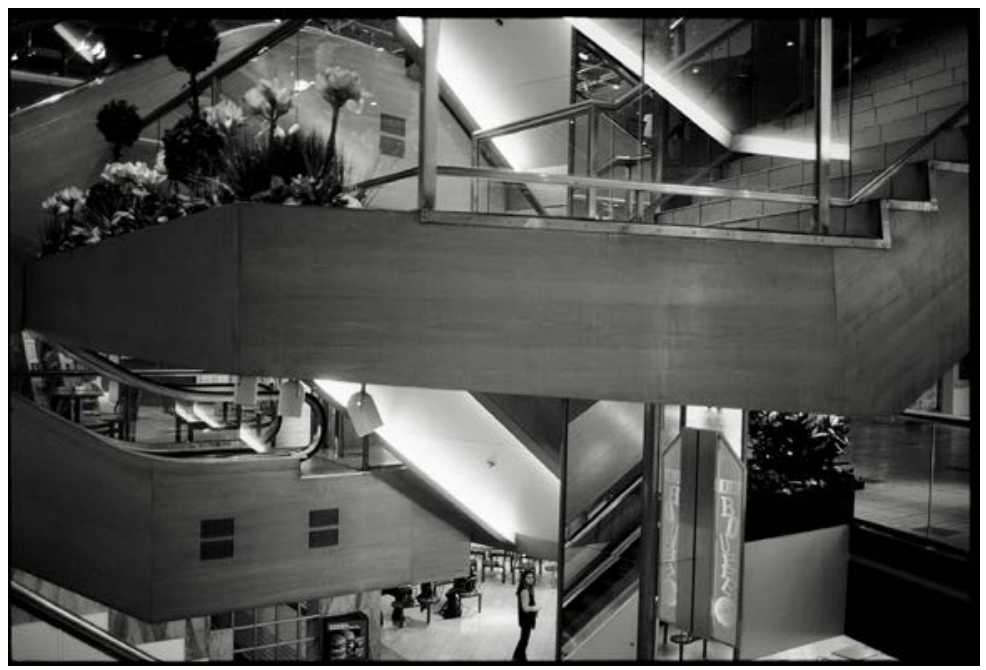

That logic and the representational effects it has gathered are visible in American urban development from the nineteenth century to the present day, which has seen the entire continental (and conceptual)
Figure 3

Montréal CA 2005

(c) Mark Pimlott 
territory subjected to a diffuse urbanism and a condition of interior, which can be recognised in the layout of cities, the sprawl of suburbs, the distribution of motorway networks, the layouts of shopping malls, casinos, airports, hotels, offices; and, in exported forms so many of us are familiar with, the images of those scenes as depicted (as ideal tropes) in advertising, television and film. This condition was critically illustrated by the Florentine 'critical' groups of architects, Superstudio and Archizoom, whose propositions for a Continuous Monument and No-Stop City, respectively, were total environments that were projected over existing conditions monumentally and indifferently, and that absorbed all forms of human activity, with the grid serving as their operative, non-representational vehicles (Angelidakis, Pizzigoni, \& Scelsi, 2015; Schaik \& Mácel, 2005; Branzi, 2006). Certainly, the legacy of this American space-that of a continuous condition of interior-has come to be recognised in urban developments and constructed interior environments far away from the territory of the United States, and in southeast Asia in particular, which, based on principles of laissez-faire capitalism and neoliberalism, follow the American precedent both in their manner of appearance and in the perceived agency of individuals within them. They propose conditions in which prescribed behaviour is required of the visitor; and yet they project, despite this, the notion of individual freedom. As these environments proliferate worldwide, they seem to constitute a normative condition; in other words, they suggest that they are normal, and public, and so they represent the notion of freedom of individuals (rather than captive consumers) through the paradoxical advocacy of the freedom of consumption and its promise of the fulfilment of self-realisation. Of course, this freedom stands at a considerable distance to the freedom we have referred to in relation to interiority as experienced by an individual in the metropolis. What might make that kind of freedom possible?

\section{The Metropolitan Interior}

Even in nineteenth-century metropolitan Paris, shaped by the immense efforts of Baron Georges-Eugène Haussmann, individual interiority and its freedoms were possible, produced by the nature of its construction. Haussmann had transformed the city into a total environment, one that embodied and represented its orders of organisation. It was devised as an enormous machine, a set of contiguous administrative arrondissements divided and connected by new boulevards, avenues, streets, above-ground and underground infrastructures, buildings, street furniture and appearances: a catalogue of codified equipment. Within its buildings, social strata were accommodated in regular and repeated 
arrangements; on its streets, a unified treatment of all elements connected with sanitation, comfort and publicity were integrated with planting, pavements and roads. A sewage system evacuated the waste of the whole, an underground subway allowed rapid mass transit across the entire construction. The streets themselves were broad and connected in such a way to ease the congestion of traffic, and the movement of police, fire and military vehicles. And yet, despite the completeness and pervasiveness of this machineenvironment, it offered anonymity as a gift to the individual: to a degree, the machine could be engaged with in ways that suited the individual's own purposes. The contemporary paintings of Gustave Caillebotte (1848-1894) show individuals, either in the street, on balconies or in windows, posed at the threshold of the city's metropolitan scenes, scenes which they seem empowered to possess. In other paintings, they are shown in groups, in the street or at work, almost as though in the service of a grand project: the metropolis, its scenes and its myriad institutions. It was quite possible for individuals to be overwhelmed or alienated by the metropolis, as is clear in the work of other painters of the city, who felt obliged to be witnesses to modern life; and in the experiences of those adversely affected-akin to shell-shock-by the metropolis's abundant disorienting stimuli, such as the multitudes, movement, and electric light (Buck-Morss, 1997; Schlör, 1998).

Richard Sennett's citing of Georg Simmel suggests that the metropolis and its effects can produce the individual's turn to inwardness. However, we are also aware of many negative consequences concomitant with the effects of the metropolis, which are exclusive, and demand the engagement of an individual who is addressed as a representative of any one of myriad 'market groups'. One must note the illusory character of these effects and the engagement they infer, from publicity and their spectacle to the pervasiveness of connective technologies that suggest personal command over one's life and relations. There are many who live and work outside the narratives of these effects and structures, who are forced to be in their service as an underclass (Judah, 2016), and who invisibly sustain the neoliberal project of a condition of interior. In response to the metropolis of the present, Sennett's use of Simmel is centred not so much on redressing the effects of its phantasmagoria but on the desirability of human engagement with others in the street; on seeing others and being seen by others, as individuals appearing in public, or, in his teacher Hannah Arendt's words, in the space of appearance (Arendt, 1958). Sennett is concerned with notions of value that emerge despite the oppressive narratives of the metropolis, and with efforts that can be made to generate situations in which awareness of people, contact between them and 
their potential interaction can occur. In such situations, interiority and its associated freedoms are produced, as is a consciousness of self among others, who appears among them and is engaged with them. It is this interiority that is valuable and is offered as an antidote to the neoliberalism's (or authoritarian regimes') coercive and anaesthetising condition of interior, its systemisation of the urbanised environment and its infrastructures (which is everywhere) to shape behaviour towards predictable patterns, performances, preferences and outcomes and its apparent adaptiveness to individual desires through omnipresent 'smart' technology.

Figure 4

Paris F 2003

(c) Mark Pimlott

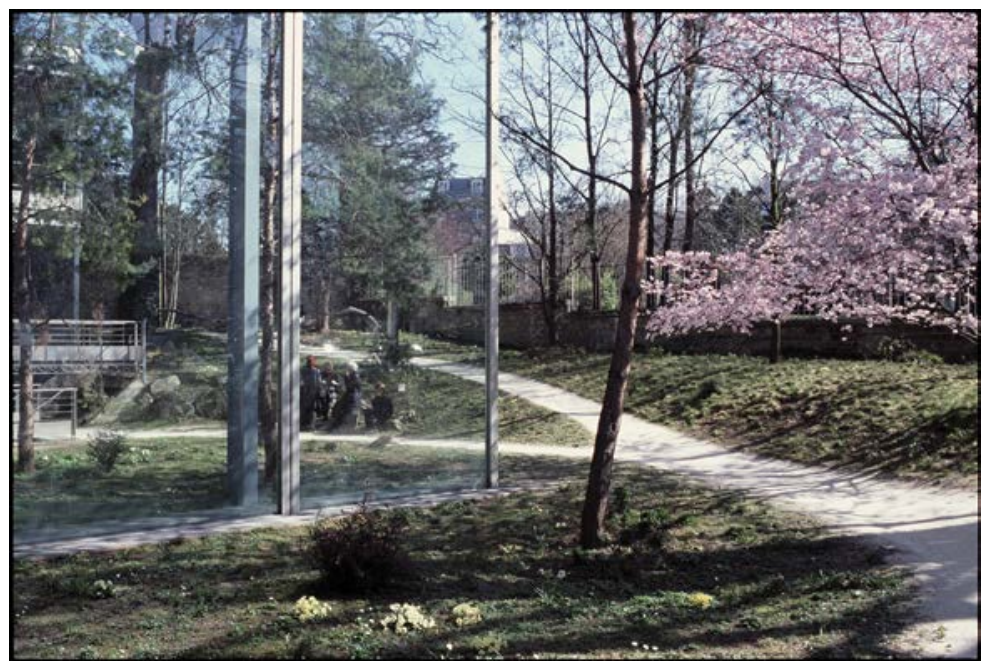

\section{The Public Interior}

The implication of the value given to this order of interiority, for designers and architects of the interior, is attention to the public interior-as that space, interpreted as public regardless of its ownership, that illustrates the values of a society and its ideas about citizens' relations to each other, to the various agents of power and to the world-and the making of spaces of appearance. The public interior can be designed to resist its deployment as an instrument and its reduction to a kind of scaffolding for coercive spectacle. Rather, it can become-as it has been, historically-a stage (Serlio, 1545) for people, upon which they can appear (Arendt, 1958; Baird, 1992), move, act, associate, and become conscious of themselves and their place in the world as individuals, as selves, as others, as selves among other selves, together and distinct, in public. In such an interior, people-as individuals, among other individuals-can be afforded pleasures of experience and consciousness and the 
freedom of personal interiority and anonymity; they can read and interpret allusions and representations through which they might occupy other imaginative realms, unbound by power relations; they can occupy real environments that evoke ideas and themes that at once reinforce experience of the present, reconcile the present with the past, and excite the imagination. Such attentions to the making of the public interior are essential to the making of material culture, and a place in the world for all individuals, all citizens.

There are several exemplary instances where such places have been made, that resonate as possible models: they are drawn from various historical periods, different countries and different social conditions; some are literal interiors, while some suggest interiors: places proposed as focused experiences. These include Vauxhall Pleasure Gardens (1650s-1859), in which people from different parts of society could meet, while walking and partaking of entertainments, frequently in disguise, which served as a model for Cedric Price's Fun Palace project (1960-1964); the spaces of grands magasins, such as Au Bon Marché or Galéries Lafayette, where people of different social classes, from shop-girls to ladies from the Opéra, could be in contact in a collective palace for consumption and pleasure (Zola, 1883) where the prices of all objects were shown; the ruins of the Palast der Republik in Berlin (1976; 1998-2006) (Ulrich, 2006), where citizens could see and participate in cultural events of many kinds in a megastructure shorn of its ideological representations; the public space and the main gallery of MASP, or the museum of modern art, Sao Paulo, designed by Lina Bo Bardi, which served as a giant shelter for human life and action, from circuses to concerts to demonstrations to exhibitions, and whose gallery of pictures proposed human relations between the works of art and their viewers; Lina Bo Bardi's Teatro Oficina (1984) in Sao Paulo, almost a corridor or street, with galleries made of scaffolding almost touching the stage that ran its length, a part of it 'missing', effectively a greenhouse with trees, affording the view of an adjacent (and currently threatened) park; Bo Bardi's SESC-Fabrica Pompeia (1978-86) (Bardi, 1996), a complex of factories radically converted for local people to read, relax, meet, be together and make culture in interiors, streets, boardwalks, pools, cafés and sports halls; De Meerpal (1967) in Dronten, a glazed shed designed by Frank van Klingeren for people to meet, play, take classes, watch television collectively, watch plays, shop in markets, look at art, and make politics (Bergen, 2003); Pontus Hultén's curated visions of culture and spaces for the public who make culture (Grafe, 2014), first at the Modernamuseet, then the Kulturhuset (1976), in Stockholm, designed by Peter Celsing, where people could read, and watch, and talk and listen, and look over the city, and immediately thereafter at the Centre Georges Pompidou (1977) in Paris, designed 
by Renzo Piano and Richard Rogers as a set of stacked fields open to public gathering, learning, living and culture-making connected to the city; the auditoria and lobbies of the National Theatre (1976) in London designed by Denys Lasdun, as platforms for people to gather to watch and listen to each other and to plays, and to watch their city in fact as they emerge from the fictions woven within; the spaces of Lacaton and Vassal's renovation of Palais de Tokyo (2001) in Paris, offered as ruins amongst which people might play as they contemplate each other and new art; and the sheltered place under the great roof of the Markthal/Stadshal (2010) in Gent, designed by Robbrecht en Daem with Marie-José Van Hee (Blazwick, Dubois, Mann, \& Robbrecht, 2010), which gathers everyone together in a big room, one that is open to the city all around them, which keeps them warm with two great fireplaces embedded in the structure supporting the roof. Like all the examples offered here, the Markthal/ Stadshal is a place in the world for each individual who shelters under its roof. There, one can be oneself (and turn to one's own thoughts) among others, in a place that represents an idea about the city-the city's idea of what it wants to be-a place whose narrative concerns relations between people rather than power, a place that is in the world and that suggests that that world is both the possession and their responsibility of the people within; a place of real material and spatial qualities with allusions to other places and other times, one that permits reflection and interiority, and is at once a shelter and a home, a place of the city and within the city, both of the present and the past, a public interior rather than a condition of interior, and so, like the previous examples and exemplars, a model.

\section{References}

Angelidakis, A., Pizzigoni, V., Scelsi, V. (Eds.). (2015). Super Superstudio. Milan: Padiglione d'arte contemporanea/ Silvana Editorial.

Arendt, H. (1958). The human condition (second edition). Chicago: University of Chicago Press.

Baird, G. (1992). The space of appearance. In D. Mertens (Ed.), Metropolitan mutations: The architecture of emerging public spaces (pp. 135-172). Little, Brown and Co.: Toronto.

Bardi, L.B. (1996). SESC-Fabrica da Pompéia. Lisbon: Blau.

Benevolo, L. (1978). The Architecture of the Renaissance volume I (J. Landry, Trans.). London: Routledge \& Kegan Paul. 
Benjamin, W. (1999). The Arcades Project: Walter Benjamin (H. Eiland \& K. McLaughlin, Trans.). Cambridge MA/ London: Belnap Press of Harvard University Press. (Originally published as Das Passagen-Werk in 1982).

Bergen, M.V.D. \& Vollaard, P. (2003). Hinder en ontklontering: Architectuur en maatschappij in het werk van Frank van Klingeren. Rotterdam: Uitgeverij 010.

Blazwick, I., Dubois, M., Mann, W., \& Robbrecht, P. (2010). Robbrecht en daem: $2 G$ no. 56. Barcelona: Editorial Gustavo Gili.

Branzi, A. (2006). Weak and diffuse modernity: The world of projects at the beginning of the 21st century. Milan: Skira.

Buck-Morss, S. (1997). Aesthetics and anaesthetics:Walter Benjamin's artwork essay reconsidered. In R. E. Krauss et al., October: The Second Decade, 1986-1996. Cambridge, MA: MIT Press.

Debord, G. (1957). Guide psychogéographique de Paris: Discours sur les passions de l'amour [Collage].

Gargola, D. J. (2017). The shape of the roman order: The republic and its spaces. Chapel Hill NC: University of North Carolina Press.

Grafe, C. (2014). People's palaces: Architecture, culture and democracy in post-war western Europe. Amsterdam: Architectura \& Natura.

Judah, B. (2016). This is London: Life and death in the world city. London: Picador.

Keiller, P. (1994). London. UK: BFI Production/ Koninck Studios.

Keiller, P. (2014). The view from the train: Cities and other landscapes. London: Verso.

Koolhaas, R. (2000). Junkspace. In Yoshida, N. (Ed.), Rem Koolhaas, OMA@work: Architecture and Urbanism May 2000 Special Issue. Tokyo: A+U Publishing.

Maumi, C. (2007). Thomas Jefferson et le projet du Nouveau Monde. Paris: Éditions de la Villette.

Pimlott, M. (2007). Without and within: Essays on territory and the interior. Rotterdam: Episode.

Rykwert, J. (1976). The idea of a town: The anthropology of urban form in Rome, Italy and the ancient world. Princeton NJ: Princeton University Press. 
Schaik, M.V., \& Mácel, O. (Eds.). (2005) Exit Utopia: Architectural Provocations 1956-1976. Munich: Prestel.

Schlör, J. (1998). Nights in the big city (P. G. Imhof \& D. R. Roberts, Trans.). London: Reaktion Books.

Sennett, R. (2016, April 22). Interiors and interiority [Lecture at Harvard Graduate School of Design]. Retrieved from https://www.youtube.com/watch?v=hVPjQhfJfKo

Serlio, S. (1545). Regole generale di architettura (libro II). Scena Satirica; Scena Comica; Scena Tragica.

Shore, S. (2002). William Eggleston, John Szarkowski, William Eggleston's guide. New York: Museum of Modern Art.

Shore, S. (2004). Uncommon places (1982). London: Thames \& Hudson.

Shore, S. (2006). American beauty: The work of Stephen Shore [DVD].

Shore, S. (2007, May 11- September 9). Biological landscape: The photography of Stephen Shore 1969-79. New York: International Centre of Photography.

Shore, S. (2008). American surfaces (1972). London: Phaidon.

Simmel, G. (1903). The Metropolis and Mental Life. In Sennett, R. (Ed.), Classic essays on the culture of cities (pp. 47-60). Englewood Cliffs, NJ: Prentice-Hall, Inc.

Sinclair, I. (2003). Lights out for the territory. London: Penguin.

Sinclair, I. (2017). The last London. London: Oneworld.

Sloterdijk, P. (2013). In the world interior of capital (W. Hoban, Trans.). Cambridge: Polite Press. (Originally published as $\mathrm{Im}$ Weltinnenraum das Kapitals in 2005).

Sorkin, M. (Ed.). (1992). Variations on a theme park: The new american city and the end of public space. New York: Noonday Press.

Ulrich, A. (2006). Palast der republik: Ein rückblick/a retrospective. Munich: Prestel Verlag.

Zola, E. (1883). Au Bonheur des dames. 